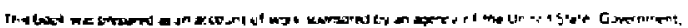

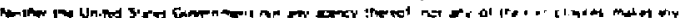

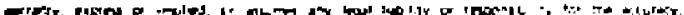
का The

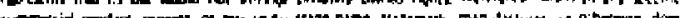

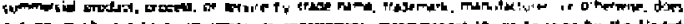

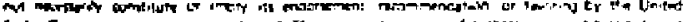

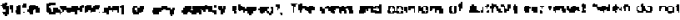

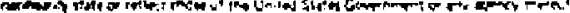

\title{
CRYSTAL BALL EVIDENCE FCR NEW STATES
}

\author{
D. G. Coyne \\ (Rewresenting the Orystal Bal1 Collaboration) \\ Stanford Linear Accelerator Cenzer \\ Stanford University, Stanford, Californta 94305 \\ and \\ Princeton University, Princeton, New Jersey 08540
}

\begin{abstract}
Evidence for three new particles observed in the Crystif BaIl detector is presented. The first particle, at 3592 MeV, Is geen Inclutively in $Y$ trans $f$ tons from $\psi^{\prime \prime}$, and 15 thus a candidate for $\eta_{c}^{\prime}$ The other two, ac 1440 and $1640 \mathrm{MeV}$, azs best seen in exclusive décaye of \& Involving a prowpt $y$, and are thus candidatea for bound ctate of to gluons. Detalled reasons are presented to support the coniention that these states are distinct from proviously observed cendidutes ouch as E(1420). Alternative hypotheses are discussed.
\end{abstract}

\section{INTRODICTION}

The neatch for new particles or stares in data from the Crystal Ball hes been concentrated In three gectors: (1) the detection of the remuling ungeen members of the charnonium Eamlly bel ow charm threshold, wuch at the $I_{1}, n_{c}$ and $n_{c}\left(1^{\prime} s_{0}\right.$ and $\left.2^{1} s_{0}\right)$ ( 2$)$ the search for new atates $x$ below the $\downarrow$ uhleb appear in $\downarrow$ * $X$, where $X$ can include $q \bar{h}$ or gr resonances as vell as wore complex objects;

(3) the aench for atatcs with open charm in the continuum obove the * Of theoe three, the wearch for the pg atates is clearly of grenteot theoretical significance, but is also Inherently most abiguoue experinenta11y. In this report, we present evidence for stotes found in caterories (1) and (2), and show that the 6 inperity analyels of the obiects $x$ lends some credibllity to the ga hypotheris.

After a brief discussion of the detector, this report considers the candidate for $\eta_{1}^{\prime}$. It then awmatizes the findings on the two new state 6 in $\downarrow+i X$. Recauge che 1nterplay between theoretical prediction and experiment has been remikably close for this chan-

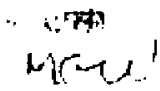

Tupported In part by the Department of Trergy, contract DE-ACO3765Fos 15, and by ketional Science Fountatic: Grant PHY79-1646).

Presented at the Annual Meting of the Livision of Particle and Fiela': of the APS, Santa Cruz, CA, Septenber 9-11, 1981. 
nel, we then present a historicol digression outilning thio tnterplay. The report procedts with an overulew of the detalled analyas: of the two new states. Finaliy, the theoretical interpretation and alternatives are explored.

\section{THE DETECTOR}

The Crystal Ball lo a fleidless, segwented spherical thell of NaL(TI) surtounding chaubers having charged-particle tracking capabilities. The detector, bullt and operated by she Cryetal Ball collaboration,1 is ahown dagramatically in Figure 1. A detalled description of the apparacus $1 \mathrm{~s}$ given elseuhere ${ }^{2}$ for the purposes of this discussion thare are several anlient parametera.

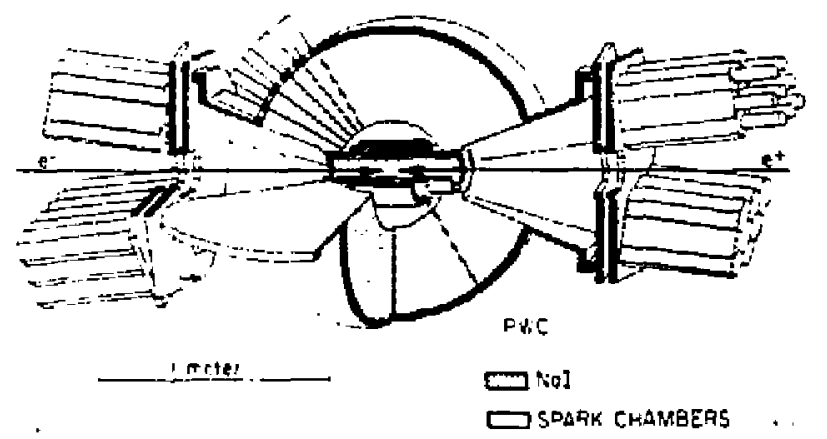

19. 1. Schematic cutaway vieu of the Crystal Ball Detector.

(a) The good energy resolution for photons is well-krown attrsture of this instrument. At $E_{Y}=100 \mathrm{MeV}$, the error of $D_{E}= \pm 4$ MeV is crucial for the inclusive observation of $\psi^{\prime}+Y^{\prime \prime}$. Less

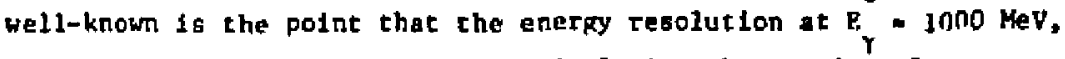

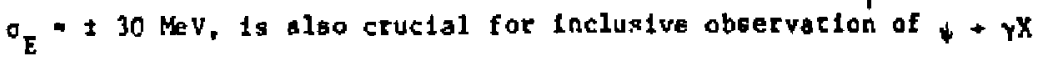
If $x$ is in the ranke $1-2 \mathrm{cev}$.

(b) The Crystal Bal I can overcongtrain events for exclualve anslyo1s. For an all-neutral final state (with the neutrale whawe ing electronagnetically) we have a $3 C$ fit -- the vertex pontion along the beams is an unknown. For additional nonshowering charged particles, one constralnt (energy) 10 lost per particle but the 
vartex eontraint is refained. One controtne is addad for aach ioterndute ane (ouch an $n$ or $n^{\circ}$ ) hypothestsod to be prasat in

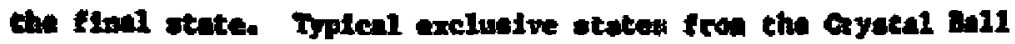
wil bx, $x$ and $x$. Coblned with the enpolis zecolution for $T\left(\sigma_{0}=1\right.$ to $\left.2^{\circ}\right)$ and chrged partictet $\left(0_{0}, \cdot 3\right.$ to $\left.1^{\circ}\right)$, the

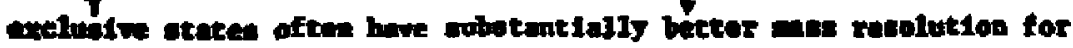
the and partieled than do the laclusive eforches.

$$
\text { III. IFE } n_{*}^{*} \text { CTIDIDNTE }
$$

Following the alncomery of : candidate state for "in the in-

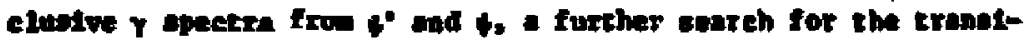

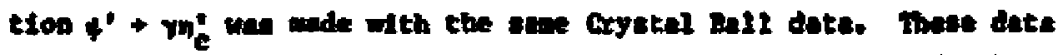
wre eubjected to refined pattern tecogntition cute doviloped cubstquant to thet dicovery. The fanlifar atrong photon Itnet cauted by tramastions $f^{\prime}+T x_{0,1,2}$ and $x_{1,2}+\gamma t$ dominate the diatribution. sall but atatiatcalig agntficent bupt epparad at photon thetFee of $638 \mathrm{mV}$ (the previous candidate far $t^{\prime}+n_{\mathrm{e}} \gamma$ ) and at " so keV. Thls latter peak wotivated addfesonal date rune ot $\psi^{\prime}$ wlah brought the totel nuber of produced in the detector to

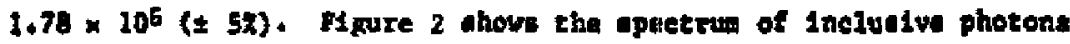

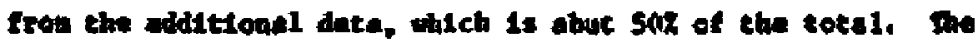

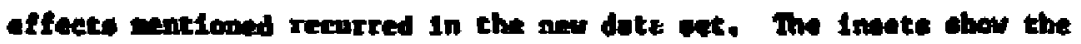

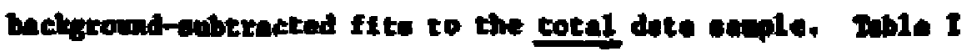

\section{TALS I}

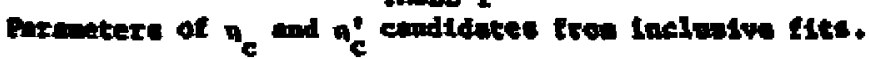

\begin{tabular}{|c|c|c|}
\hline & $n_{e}$ & $n$ \\
\hline$\langle 2\rangle$ & $638 \pm 4 \mathrm{~kg}$ & $91+1 \mathrm{mv}$ \\
\hline H & $2978 \pm 4 \mathrm{VV}$ & $3592 \div 5 \operatorname{mp}$ \\
\hline $\mathbf{r}$ & $12.4 \pm 4.1 \mathrm{H}=\mathrm{V}$ & $\left(9 \mathrm{mV}\left(95 \mathrm{C} \mathrm{C}_{0} \mathrm{~L}\right)\right.$ \\
\hline sIgnificance & 70 & 4.4505 .10 \\
\hline $\operatorname{Br}\left(\varphi^{\prime}+y+\right.$ ocace $)$ & $(.28 \pm .08) x$ & $(0.2-1.3) \%\left(95 \% c_{.} I_{\phi}\right)$ \\
\hline
\end{tabular}




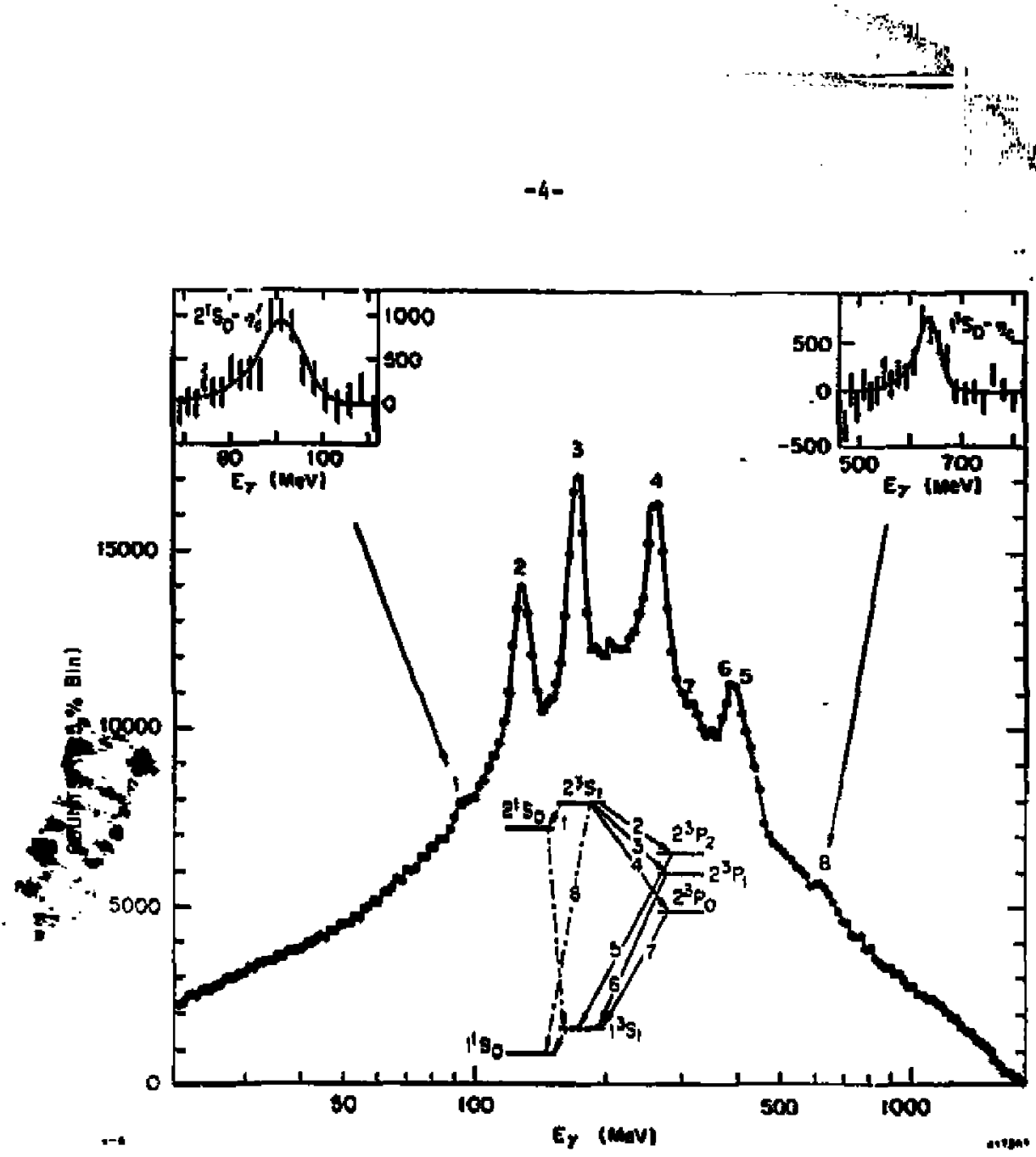

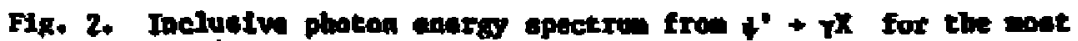

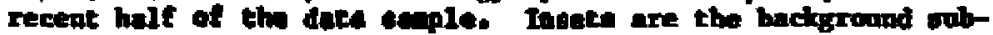

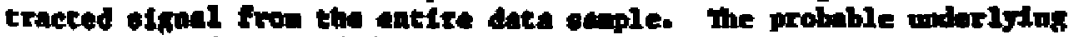
tern diater is inciuded.

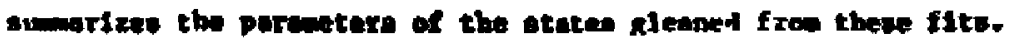

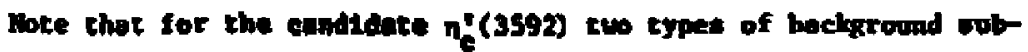
craction whe porforma, The inset ghour the least reatrictive technique, In wheh the bekgronind polyootal is allowed to attelut to fic the bup. Mother echod fite the tackproum polynodal alone to the reption excluding the peak (74-1no MeV) and then conatrafne the beckfround to this result for the subtraction and aubsequent

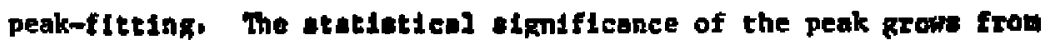
4.4 to 6.1 s.d. For this thange in technique as expected if the backgtound "robe" the pak In the tormer pethod. The nacural fult 


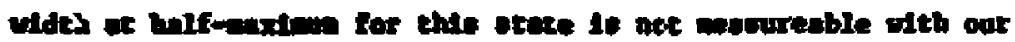

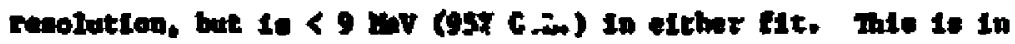

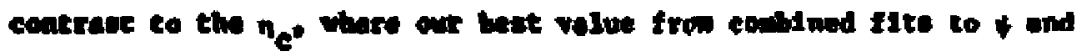
t is $F_{n_{e}}-12.4 \pm 4.1$ not.

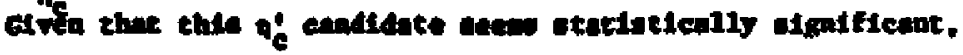
the effect wat by cheiked for the poufibilfy that it 10 ajeteratte. in Invatigntion of unch poulbilitses has been reported by

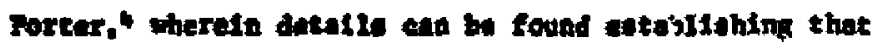

(1) These ere no byatintte affecto in the spectra of charged purticies, dther zon or tlectelous, which con feed Into the photas opectro through the Astdentification of a chorged partiele as noutral.

(2) There are the obytous exelusive chandele, such as

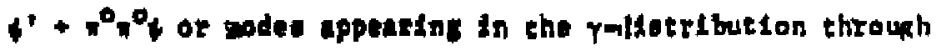
atcidenefficition, whith produed a spuelour $t$ line at $-90 \mathrm{HeV}$.

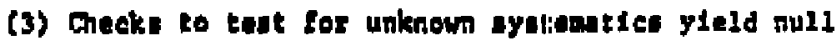
resulte. There tase include a paralial itentical incluatve

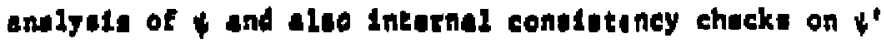
whleh look for the almet in date subset dividad wth respect to geowetry and the.

our conclunion is thet the $\pi$ : endidate it tully on e per with the previou n cenddate, Insolar as the $\psi$ ' Incluetve phozone sre concerad. It Ieck the undul complonentery evidenee frow an e1-

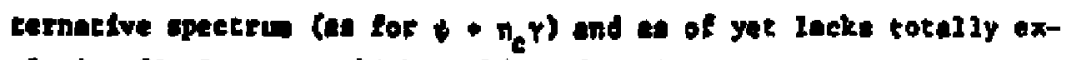

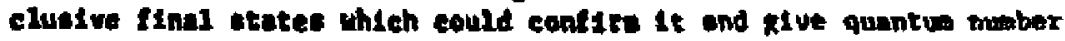
deterinationa.

Jowe hat betn one proviout references to a postible n' teke near thio ase, wasured in the easede reacion

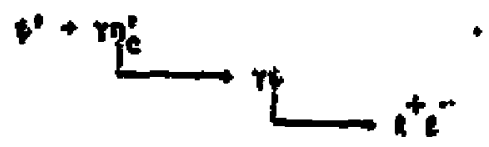

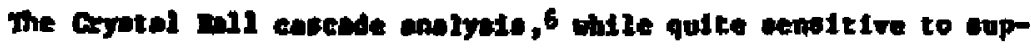

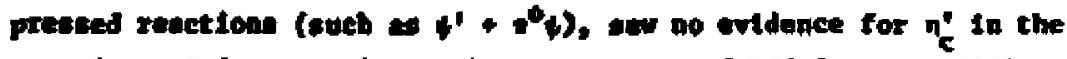

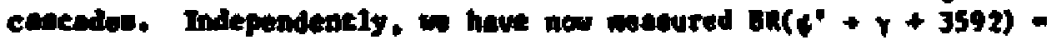


0.2-1.32 (952 C.7.). The expected $n_{\varepsilon}^{\prime}$ with $(01$ won ond the rate

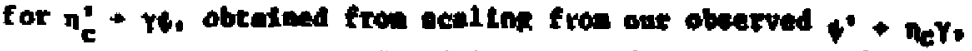

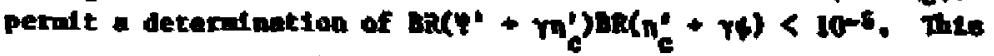

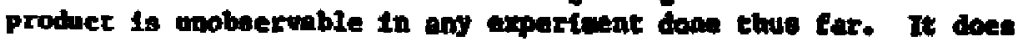
not appenr thuc ow present $n_{c}^{*}$ candidate is salated to the fotne.

T. Wist sthes mon osed

Two new acatee have onerged frow the atody of $\psi+r x_{1}$, wth subsequenc excluadve decay wodes of $x_{*}$ the have nawd the two wated $1(1440)$ and $\theta(1640)$. A 14tt of the propertion of thase states at derived from cryatal bell duta is atwa in mble $\mathrm{II}$.

TALE II

liew atates 7500 d deay.

\begin{tabular}{|c|c|c|}
\hline Neme & $1(1440)$ & $0(1640)$ \\
\hline Mage & $1440 \div 20 \mathrm{Mov}$ & $1640 \neq 50 \mathrm{mav}$ \\
\hline$\Gamma$ (intelnafe) & $70 \pm 20 \mathrm{MaV}$ & $\begin{aligned} 220 & +100 \mathrm{M} \\
& -70\end{aligned}$ \\
\hline $\mathrm{J}^{\mathrm{PC}}$ & $0^{+}(99.9910 .2)$. & $2^{++}(952$ C.L. $)$ \\
\hline observed Decay Wode & $1+8(080)+7$ & $\theta+m$ \\
\hline $\begin{array}{l}\text { BR }(\psi+Y+\text { tate, } \\
\text { state + oberved decay })\end{array}$ & $\begin{array}{c}(4.0 \pm .7 \pm 1.0) \\
\times 10^{-3}\end{array}$ & $\begin{array}{c}(4.9 \pm 1.4 \pm 1.0) \\
\times 10^{-4}\end{array}$ \\
\hline
\end{tabular}

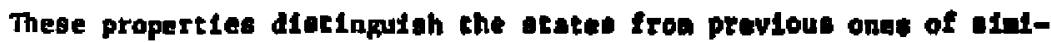
1ar wasget asolgned to qq nonete. w weh, the now ototos atiory the aindes I requiresent to quolify at beund stotes of two gluons, bat that agsignont is not unique. to wil diseves alternoke cholces.

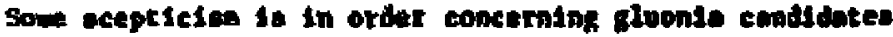
because of the large nuber and varlaty of (o) ototes watable in

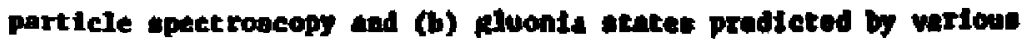

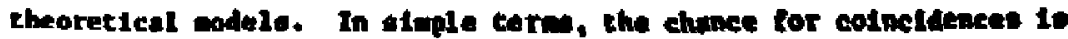


Iorge. A good deal of our enthosiagm for theas lateat cendidetes aten: from their appenrance ir a pirticula place judged a prtort to

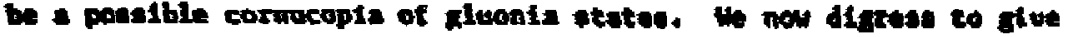
- atech of the histary of weh opeculatiose.

Spoulation on Giopile

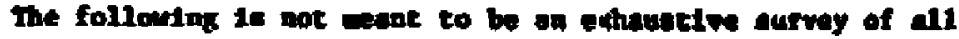

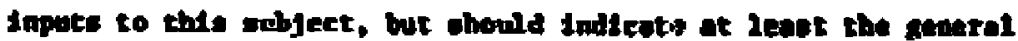

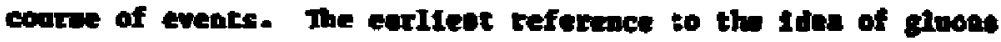
bound to glwons occurred alwont simultaneosely wh the eensept of the now-1helfop rroup atructure of the field quonte. lonk befote cen

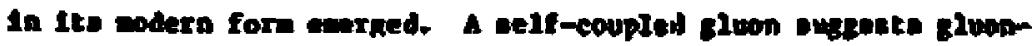
only bound atotes. and references to such wert ade early by Mabu (1956), Frtecach and Cell-Wann (1972), H11kon (1974) and way

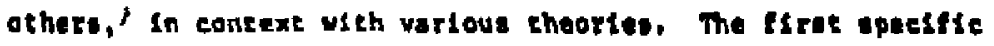
prediction for the two-gluon changel in theayo wa ande tor the 1dealized case ox corplately noninterceten! Rluons by Chanowlegs (1975), who considered the procest $\downarrow+$ rat + al1 hadrons. This was ealculatcd as if the YBR were virtual and lihn dicappearod in the final stste, but the eransition ygg - hadeind wa taken as unit probability. The effective renult was the large branehtng ratio

$$
\frac{f(t+x(t)}{r(t+x+2)}-\frac{16}{5} \frac{5}{5} \cdot 102
$$

Citp and boloring (1976) choued independently thet the process \& The should be Identifiable by the vitque spectral distribution of the rent $y$ (Figure 3 . which entaine woet of the rote et letge $*-E_{y} / t_{2} w_{t}$

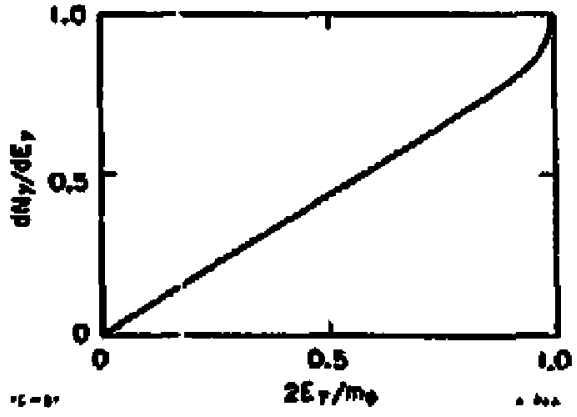

P1g. 3, The spectal detribution for the phtiton expected in t + rag, wth Rlupau anesines and noal ntercering. 


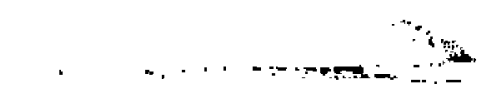

The realitation thet the ranl y could probe the gleon-gluon masa upectrom appeared In a work by Btodaky, ot 1.10 (1977), vare the $x$ - and angutet-distributlans of the $y$ for moninterecting $x$ from

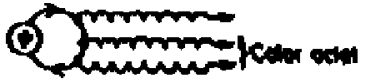

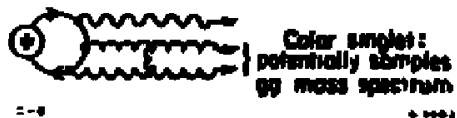

Fik. 4 color equbinntions postble tor two tuons in $\$+3$ and $4,3 \pi$.
$T$ and $\$$ - ratk bere coin-

sidered. [That the it in

11tely plece for such bownd otate to eppear in elear from Figure 4. It alrow that In the Atundard 3-gluon decay of $\&$ (a color singlet), any exp pluons cannot be in a color anglet because they need to comblnt with the remuining givon (o

color actet) to forw the 4 . In the process 4 rgr, however, the $\mathbf{z g}$ are forced to be alinglas beesue the $r$ 10 colorless, and thus the Y potentialiy cabples the $g$ ara apnetrue of real particlea, $\left.\right|^{11}$ Brodgky wade this expltate by showing hew a go resonance would appear in the ineluetve y opetrin (Figute 5). Even nore speculetively, Koller and Waloht2 (1977,1979) presented 1ndependent args-

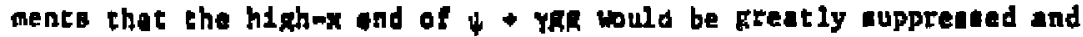

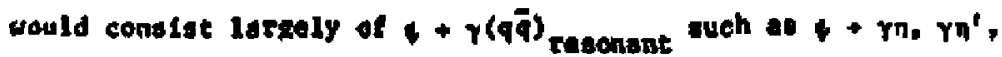
Y. An very low $n$ they expeced the prediceton for $\mathrm{Yax}$ to be

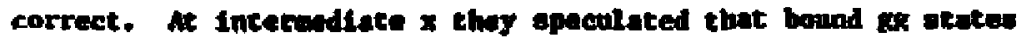
conld greatly distort and adulate the $y$-opoctetis. Expore 6 is dertved from that arilate paper (the seales hov beà modtfied for compariest wh Fiqure: 3, 5, and 10). Oa: wat kop to ato thot experdecatally these photon olanele all appect cuperposed on wuch larget replaly Elunk $Y$ background frow $7^{\circ}$ deeays.

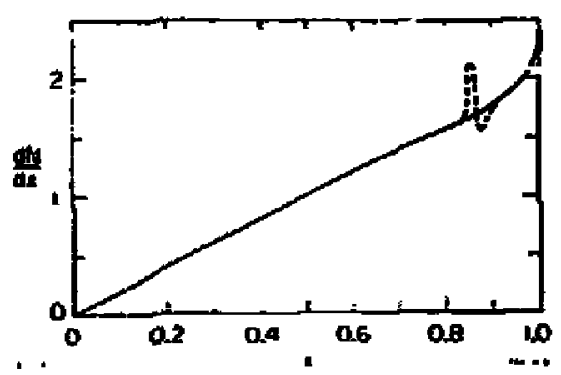

Fig. 5. Hodulations of the 1neluolve $r$ entrg spetive in $t+$ the expected by reanances in at. 


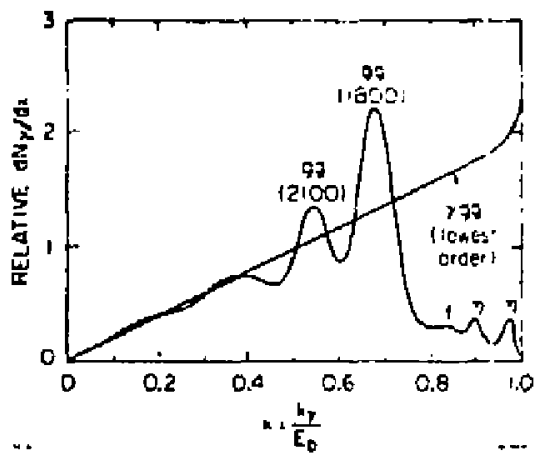

F1. 6. A nonquantetetive prediction of euppreations and codulatione of the inciustve $Y$ enerfy spectrul in + Ygg. Masses usulgned to bups are only ta fllustrate the approxiante x-regton and have na daeper eignificence. This plot is derived fron the source, not reproduced.

A Iarge nuber of predictions of variove types has followed these early paperu. One 10 particular (Bjorken 1979) 13 deservea mention, beigg of explicit a pradiction as ever appears, given that 1t predicte an approxiante asa, the best production and decay channels, the rate, the background and even the specific detector. te reproduce it here:

"But an even core Intereating question to what 11et beyond. TE arrow gluonie atates doninace in the reglon from $x-1.4$ Gev to $H-2$ cev, they should provide $\sim 30 z$ of all radiative decay nodes. The $y$-ray energien are $1 \mathrm{GeV}$, and probebly badly bueled in contaninetion fron $n^{\circ}$ decays. A 27 y-ray enizggy resolution correaponds to resolution in gluonium wase of order $30 \mathrm{HeV}$. It ay be unreals: ic to cry to remolve ay gluontua lines by menurenent of the recoll y-raya alone - even uaing Cryetal ball -- and reduceton of background by looking for exis?uatve glwoniun decay channels woy be needed. Hire one wight try for wowe of thase involving neutral dicnyb, e.p., $\eta$. We it w11 be difficult. A scenario spproptiate 
for the Cryatal BaIl might be

$$
\begin{aligned}
& 4+Y+\text { gluonilo } \quad 1 / 2 \pi
\end{aligned}
$$

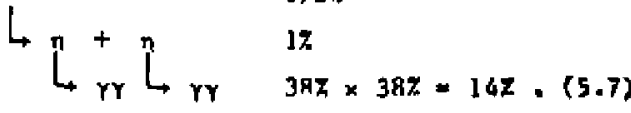

The net atgnal 1 a -7 event $8 / 10^{6}$ decays, even with rather generous branching ratto assuged for the nn decay-channe $1 . "$

\section{Initial Experimente on $\psi+$ rgR}

With this theoretical tootivation, experimenter were looking for these spectfic features after each was predicted. J. $S$.

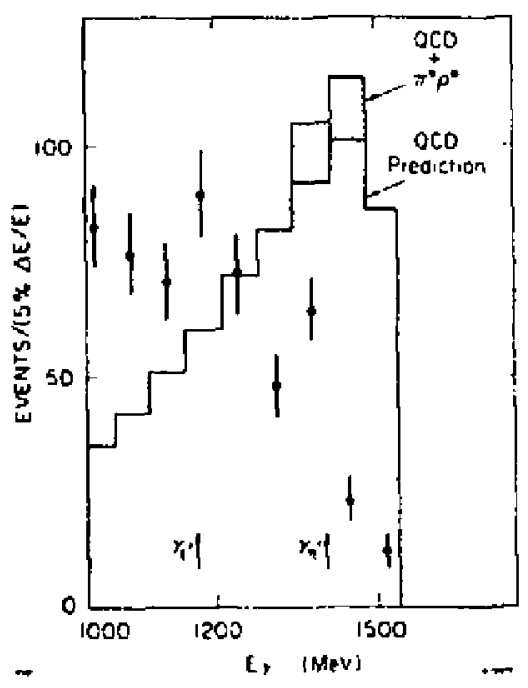

F19. 7. The unaubracted high-x end of the spectrus $\downarrow+y X$ (data pointe) (SP-27). The histogray 1. the lowest order OCD prediction with and without the procese $4+\pi 0_{0}^{\circ}$ (which 18 Indistinguishable from $\left.\gamma^{\circ}{ }^{\circ}\right)$, The arrows indicate where $n^{*}$ and $f$ ' would produce $Y$ 's, for the purposes of tenle.
Whittaker 14 (1976) fitct

at terpted to see the $h 1 g h-x$ peak in $\downarrow+\gamma$ rg in the Hark I data, with an inconcluglve result. Nother actempt to measure the 4 end point spectrum vas made by Emall soldd-angle, high tesolutJon NaI detector at SPEAR $(S P-27) .15$ White no ${ }^{\circ}$ beckground subtraction was posalble, 1t was ohown (P. Hore 1978)16 that the sharp high-x peak expected had not materialized. Figure $?$ shows this result and indicates the equivalent ifmb $a_{5}<0.05$ ( $95 \pi$ C.L.) that an unmadifled theory wald need to hide the effect in the $\pi^{\circ}$ toil above $x=0.8$.

The f1r6: Indicetion of a nonvapishing rate for $\downarrow+\mathrm{TGS}$ came from the Lead-Glase Hall deteccos (Plonan, et 1 ., 


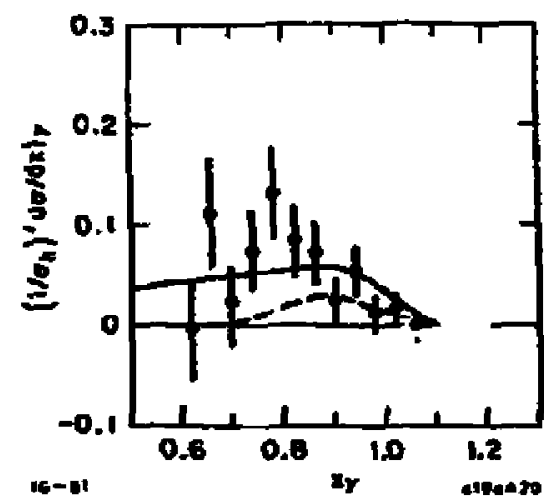

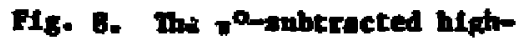
$x$ end of the apectru $++7 x$ (Leed-Giass Wall). The soltd ine is a fit to the lovant order oco calcuistion, wile the dabed itne in that part of the rate attributable to know channels of $t$ radiat ive decay.
1979).17 Figure thowe the brosd, Indiotinct. elgarl after subtraction. The shope us dotend constetent wth the theory, after lerge discortipns by the pot-rovelution showet decectors. The branchidos ratio une 2 te $62(0<x<1)$. Drtdance fot a eanterlbution over that proviaualy weroused for

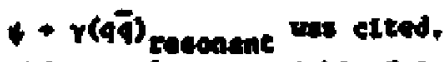
This renule wat quidkly followed by a knth II andegous tousureDent (scharre, at a 2,1979$)^{16}$. Pigure 9 thowe that aven with poor phozon resolution, the Rrantly Itproved ctakdotted

prection zules out the high-x peak ortginnily predieted in 14 YRR. Mowever, the branching ratio (3-3t above $x=0.6$ ) is not in disogreement wth theory. These two experiwonts showed that the prompt $\gamma^{\prime}$ exhat, but that the almpte oct caleulation hed to be podiffed -- a concluston ealily nccepted by thertete who vere bepinolng to cee large cecond-order correckions oppear in releted colendectons.

When the Cryatal Bell dats. on the ${ }^{\circ}$-suppresead ILth-x 10 closive 1 spectru betene watlable19 (1979), it we clear that the propt y algal tan rich In struetore (PIgure 10). Hope were tlesely vatble at $\gamma$ energles corresponding to radiatve traneitions to $n_{1}$ $n^{*}$, and $\mathrm{m}$ - $14.50 \mathrm{Ki} \mathrm{V}$, with hint: of effects iseubere in

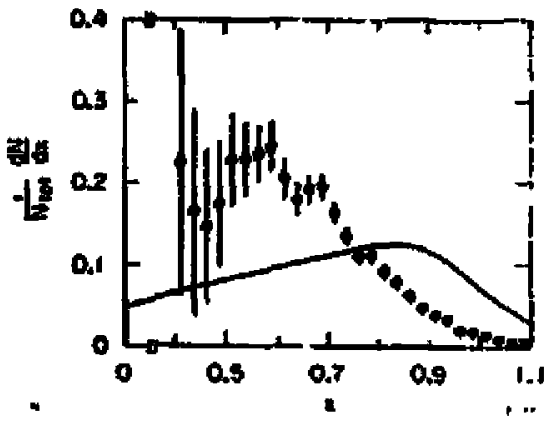

Fin. 9. A for Mgure a, except for revk JT date. 


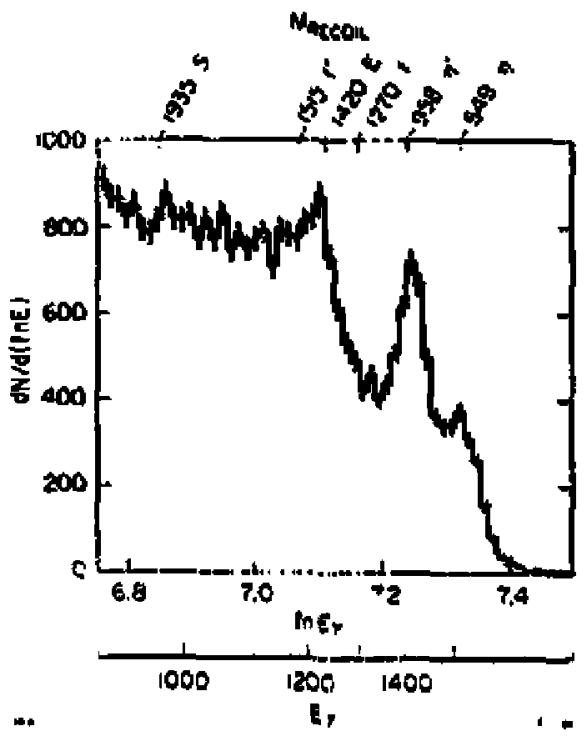

Fla. In. The uneuberacted hlgh-x end of the spact rua $\psi+\gamma \mathrm{Y}$ froe early Cryotal and deta (eweor 1979). The particle nases along the cop of the araph warve at seade warkess, not as eselgneants of typothedes to bump in the opectruen. the apectrus. Writ to f1n exclustve channols $1 \pi$; drcoy culndnated it the detection by the Harl II (Echarre, 1979) 20 is $1+7 x^{2} x^{0} \pi^{*}$, by the cryetal Dell (Archan, 1979)21 in $4+\mathrm{T}^{+} \mathrm{x}^{-}{ }^{\circ}$ and pouplbly in

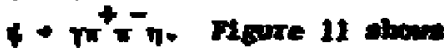
che latk II realle, there the $k^{t} k^{0}{ }^{*}$ eleorly revonte near $1440 \mathrm{raV}$, with atrong suggestion that $\mathrm{KR}$ are reaonant it $6(980)$. In response to these dara, Chanowitz, Donoghua at 81, and Ithikewe22 (1981) have Independently proposed the thid reaction coutd

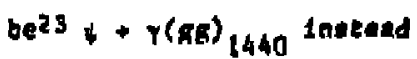
of $\downarrow+\mathrm{rE}(1420)$. where $E(1420)+x^{*} x$ hat lang been

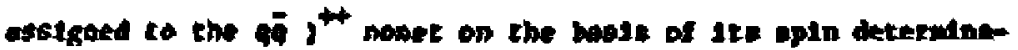

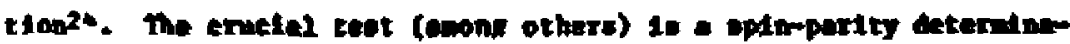
tion of the abject aen in topes.

The Cryetal bil detuetor has ben taking wore date at the 4 . rouphly doubling the date anple - the total caple is now $2.17 \times 10^{6}$ t. the now contove with a diwcusion of the new etukats ceon in these acoys.

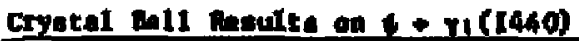

The updated Gryatel ball rebult for $+\gamma^{+} k^{-} w^{\circ}$ for the entire

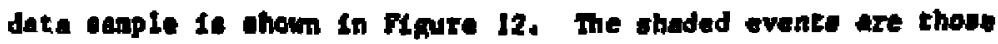

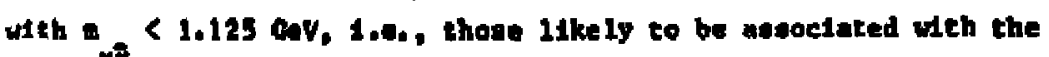
k. tatl of $6(960)$ (eht canteal value of o ie belos $k \bar{k}$ threnhold). The 


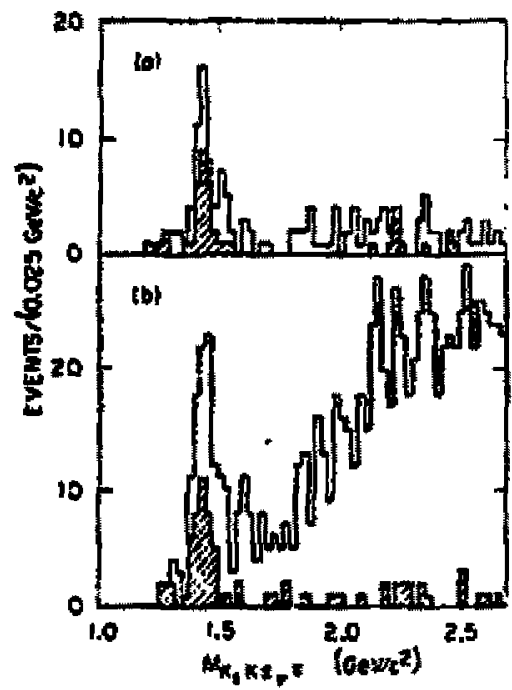

78. 11. The 1rvartant $\mathrm{x}_{1} \mathrm{~K}_{\mathrm{n}}$; ate apectrut fros che refiction $\nu+r R_{n} x_{T}^{*}$ (Mark $I I$ data). The spatat rum with a detected $Y$ 1. Rtvan in (a) and with no cuch rastrigtien in (b). Eroeshatehad epecte corresperte

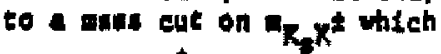

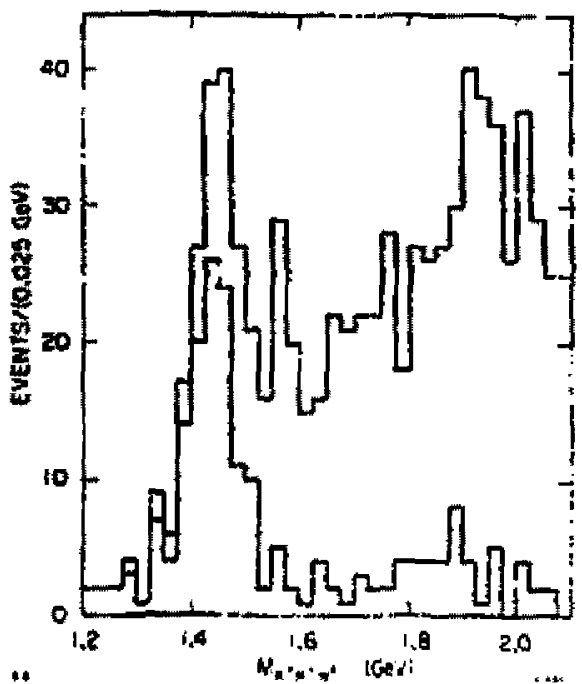

F1g, 12. The tpectrum anatogous to 51 guts 11 tor the thetre data sample eros the Gryetal Bald,

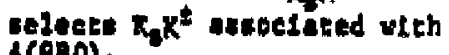
6(9BO).

corrobpostst inelustve, dietribution is show in Figure 13. The width of 1 in the Inelustve distribution should be doatnated by the enercy rusolution on the $r$, wereas the exclusive fit reduce the

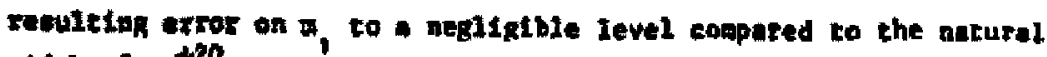
wdth of $70_{-30}^{+20}$ wt. "Thble III ahoug che comparison of chene errors.

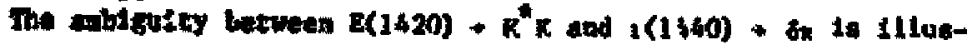

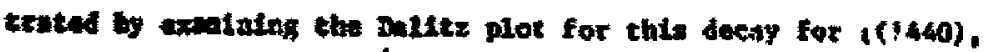

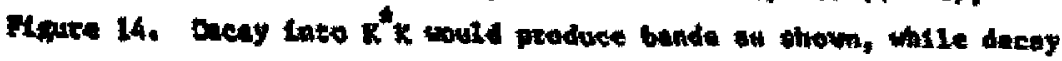

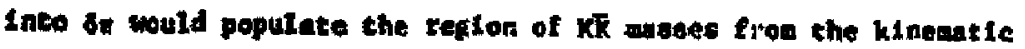
boundsiry up to the $\mathrm{k}$ ane eut chosen. The lattut hypotheals lookg

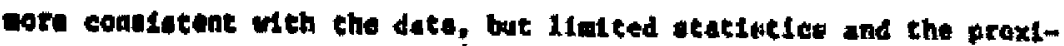
aty to the boundary of the $R^{*}$ bands obecurea the iniarpretation. 
TABLE III

Pewolutions tor Inclustve and teciustive $\phi+\mathrm{t}$.

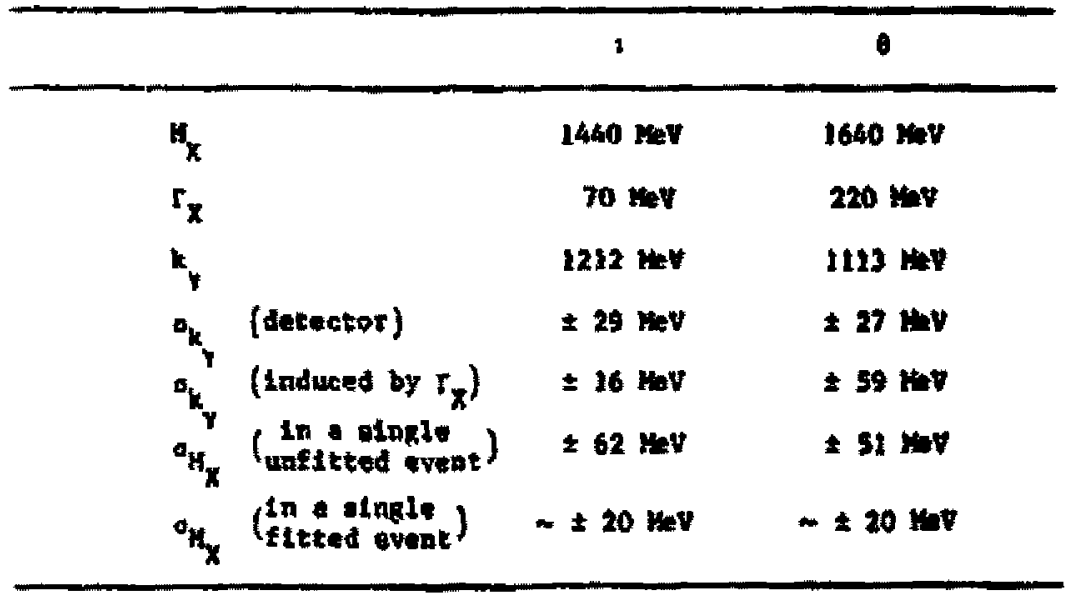

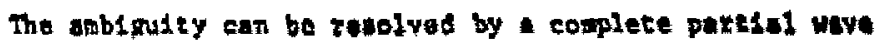
araly ls of these dace. For added detallo of this analyale ane Scharre.25 The analyote is

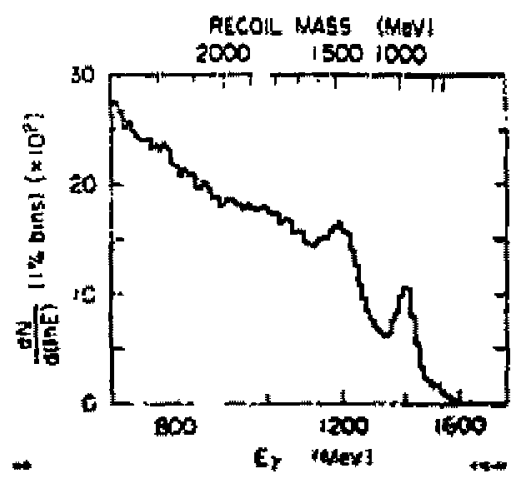

F1g. 13. The apaction analogivs: to Fig. I0, be frou the enetre Cryatil eall dute atuple. sowe beckground-suppresulng cute applied in rig. 10 have not been used here. carrled out ualng lour cohnent:

partial wava aplitudes

together with a nonpobstent

phose epace enplitudes

t $r x$

$x$ - 0 (phate space)

$6^{\circ} 0^{\circ} \quad(\sin 0)$

to $\quad$ (epta 1$)$

$x^{2}+\vec{x} x$ (epin

$\mathrm{K}^{*} \mathrm{R}+\overrightarrow{\mathrm{R}} \mathrm{r}$ (apta $\left.\mathrm{n}\right)$

thile these anplituda do not sxhauct all poastbiticted, tho eerve to clartify the uwly

alternactues. The racule of 


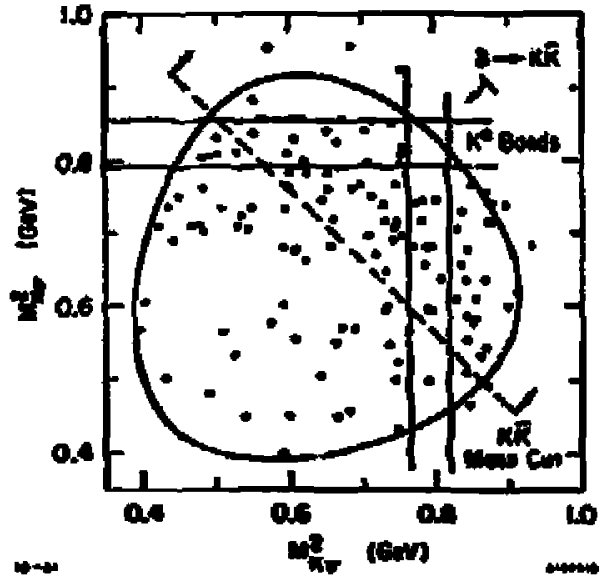

Fi. 14. The Daties plot for the Creay $1+\bar{X}$. for the total Cryeter Bll date omple, itth $1.4<0.0<1.5 \mathrm{cav}$. $x^{+}+\mathbf{x}^{\circ}$

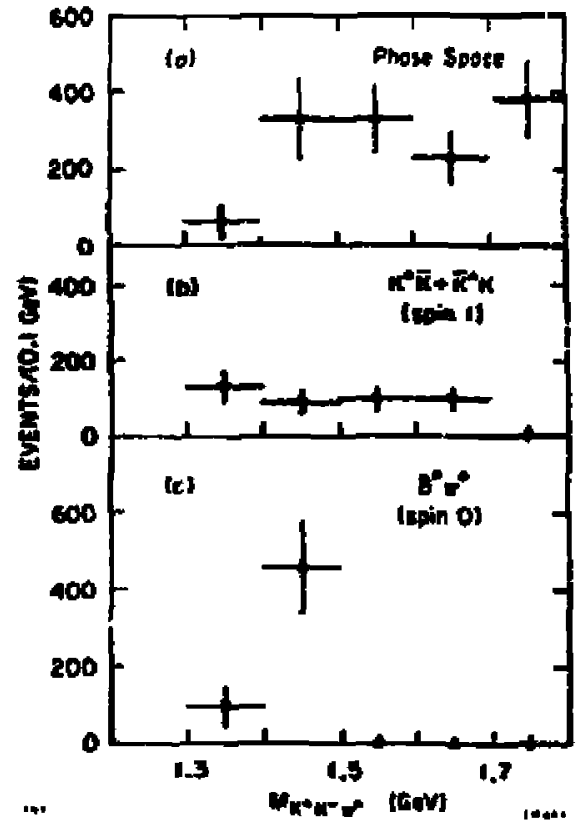

the ste to the dete is thom in Fifite 15, wate che alfatflent miltudes are ciopleyed. 0.15 80 (opin o) dhow any resonent fore natr the mp obverved in 1 . The totnl concrtiveloo of

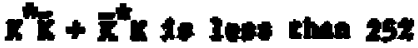
(Sol c.t.) on in nonreworat. In otere to gats - feclias for she enlats probebiticles of thete aplutudes, If one aplteude (plun phand spaed is to explain the ditertbuttct, fate whe ade

F1F. 15. The $\mathrm{K}^{+} \mathrm{K}$. dependense of thi curvitung partisl wave onpletedo for 1 + xin (Cryotel vall deta). 


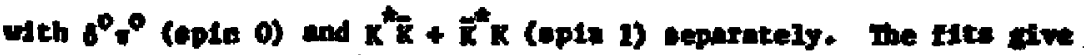
the probubilty the ${ }^{*} \bar{k}($ spin 1$)$ een explain the date to be only 12 of that for the $0^{\circ}$ (epin 0 ) hypotheslo. Mternatively, if the soplitude 1t fosend to be $t^{\circ} \mathrm{c}^{\circ}+$ phase spaes, the probubility for apln 1 If only $10^{-4}$ of that for spin 0 . The cowpetition anong these

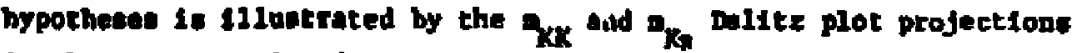
In the a aes refton (Fipures 16 ond 17 together with their

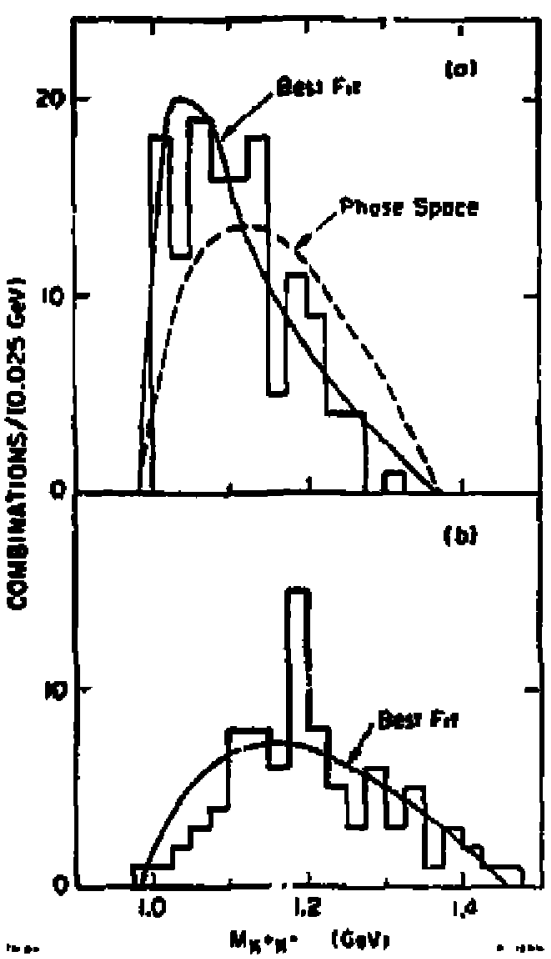

Fin+ 16. Frojectlons io of the $x^{+} x^{-0}$ antite plot $\mathrm{f}^{+} \mathrm{x}^{-}$ (a) $1.4<=1.5$ ces and

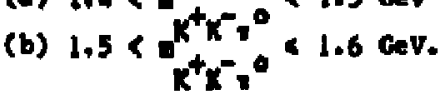

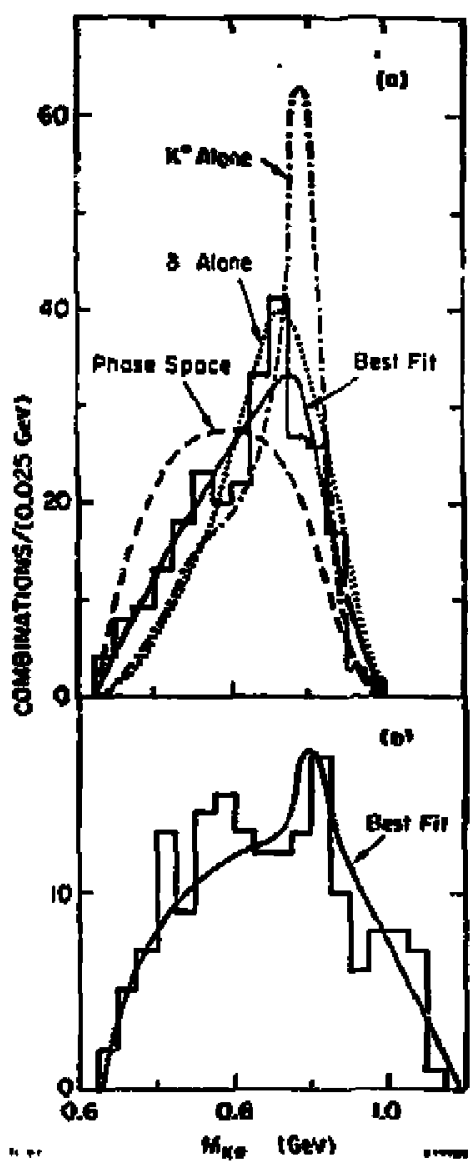

F5. 17. Frojections in m. olatlar to Fig. 16. 


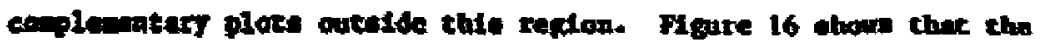

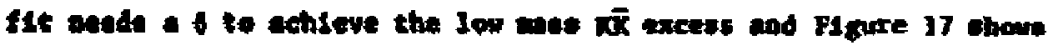
thit the fie canot tolerate $x$ t alone, wheh cruace top extre- :

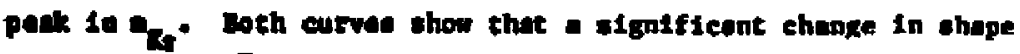
eccure in the akr sase rogion adjacent to the 1 . The conclution to wheh all of this andyete potats is that che,$(1440)$ it a $0^{-}$etate

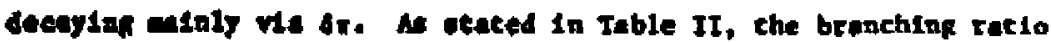
produst is

$$
x\left(y+r_{2}\right)(1+k t)-(4.0 \pm .7 \pm 1.0) \times 10^{-3} .
$$

wast the firut etror lo stotiotical and the sesond is gyotengtic.

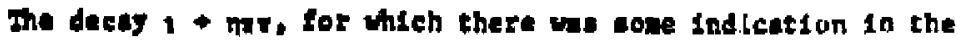
proliniang date, hat not got beta quantified it the present gaple. It atgt be expacited fron the decay $s+n \pi$, but the Inforation on $\delta$ decay do dot daftaltive enough to pentt a manfigful prediction. Cratel Lall Daqute on $+r a(1640)$

A warch tor an bound ctatet decaytng into nn was begun laned1ecely lolloulng Bjorken's uuggestion.13 After ficturulotion of the

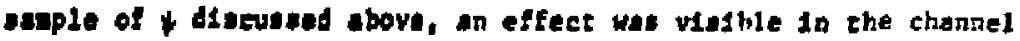

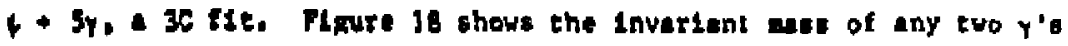

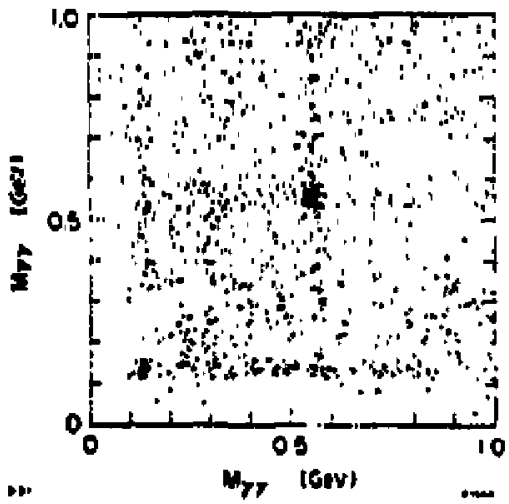

H8. 18. secterplot of a we a for ell fifteen con bloaktone of $r^{\prime}=$ from $t+5 \gamma$ (Cryetal Bell date). plotted aguingt the invariant nag of anj' two ochers (15 coor binatione per event). S1grals correspondag to $\&$ + yn and * $y^{\circ}{ }^{\circ}$ tre geen, with a larpe beckground that is minly conblastorfal. The 5y eqenta ere flt to the hypotheols 4 - yn (5C) and the invoriant mase of $n$ in 10 digplayed (Pigure 19). An enhancewant emerged at a waed of 1640 the with a large but uncerzaln intrincic vith of $220_{-70}^{+100}$ Mev. Table III 


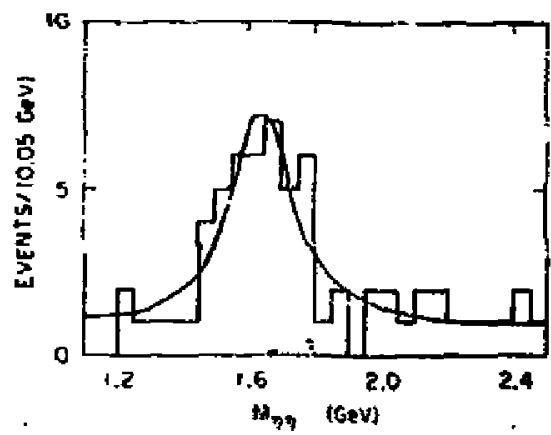

PIF. 19. The lavertent wes

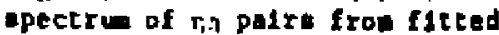
Crystal and events of the type $\downarrow+$ rnn. The aolid curve is the oum of a Briet-Higner term and otoll conetont beckeround terw.
11 luatrated thet althoun th precteion In the onses of the photon and the fitted wod aro very antlat to the cate for the $1(1440)$, the notural wdeh of thie object dondrintes the expected wadth of the trantition r-line In the Inciualve repectur. this broadenting ukat it harder to see, and Induad ve aee no clear evidence of this otate in the tocel inclustive itople (TIpure 13) uniute te corresponds to the broud excene to the left of the vialblo $1(1460)$ peak. The

Inclustve $y$ distribution of 5y evente slone also shew se pahing at the expected $k_{Y}=1113 \mathrm{kev}$, but the nnr wode to enpacted to be scatistically Inundated by buckground.

We heve nased this candidate atate o(1640) in a thinly vatied atcempt to acknouledge the acuity of the gotivator of the ourch, and os the onjy rational clternative to the unacestable nome $\mathrm{B} / \mathrm{s}$,

The stace has been wearched for in othar channele, wh no wbstantial result. In the chanael $\psi+\pi^{\circ} 0^{\circ}$, where tha dontnant $\pi^{\circ}{ }^{\circ}$ effect to te $f^{\circ}(i 270)$, there 19 a oungetion of in effact at 1640 (Flgure 20). Interproting als the evante above $\mathrm{f}^{\circ}$ in this

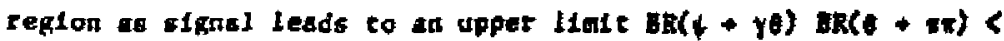
$6 \times 10^{-4}$, which is clearly not restrictive alven that $\operatorname{BR}(\psi+\gamma \theta) \operatorname{BR}(\theta+\eta n)=(4.9 \pm 1.4 \pm 1) \times 10^{-4}$ is found in the other channel.

A spin-parfoy analysts of the $v+$ inn eveate has been ends, 28 Boge oratiot. a restrict the low value apin ctatas to $0^{+}$or $2^{+}$, the three Independent angles used in the fitring procedure ort obom in Figure 21. The procedure was vertfied by applying it to the $+\mathrm{Y}^{\circ}+\mathrm{Yr}^{0} \mathrm{x}^{\circ}$ atate, where it excludes oplt $\mathrm{O}$ by an enorwous 


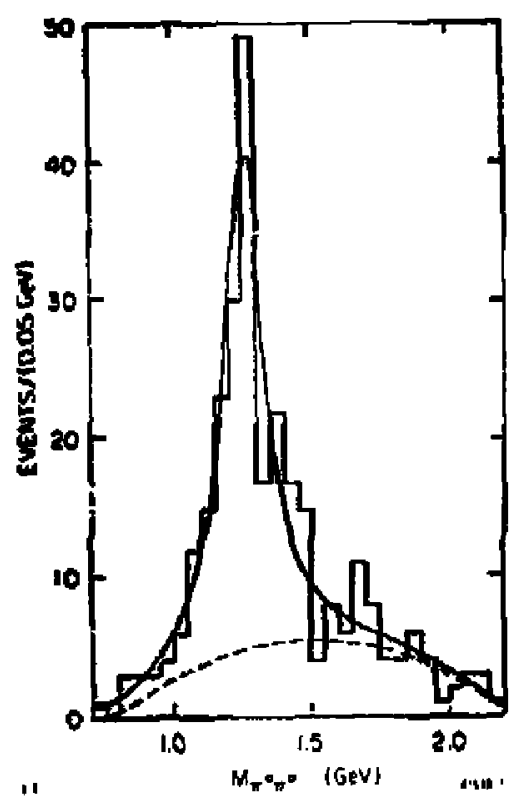

718: 20. The mess spectrum of $7 \%$ fros Eltted crystal Bill evente, including the eost comong oned were the $\tau^{\circ}$ is noc deetingutethable an $2 y^{\prime}=$ and thu does not eppenr in the proviens eat t $+5 y$.

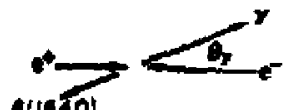

oristor
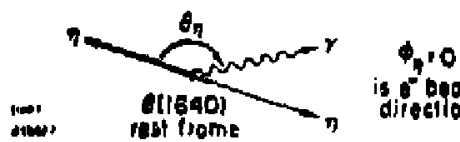

is irection

71. 21. Metinition of nafles var in the optr-pintity analyute of the o(1640). tectory we wete that weh of che Agatficance of chis exeluolen wa atoloped fros the Hitud ${ }_{Y}-t_{n}{ }^{-b_{n}}$ correlations. the cone procedure applited to $4+$ o gtelds the renult that Probabilicy ( $\theta$ 1s spin $D)$

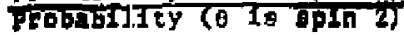

$-.045$

plus sowe constraints on param ceere of the spin 2 ancular diecthation. Tiv two beandard deviation reaule may atso come firon correletion +ffects, wit $1 t$ appents thet on extrtimin of the coso dstribution wufices to explath the preterence for $6 p 1 n$ 2. (F1gure 22, $\left.\operatorname{legse}_{n} \mid * 1\right)$, This retult pake the iplr deterolation complatit leas compellingt cleaner deterniarion vat mate sore data.

Puptbie Theoretical InterPetrition of the hen Sente

The establiahment of bound state of two giuene would tmpone severe reatrickions on the dyanics of $O C D$; $1 \mathrm{t}$ is thu: prudant tc examine altarnotives to this interpretacion of and 6. Table IV lista only a Ev 


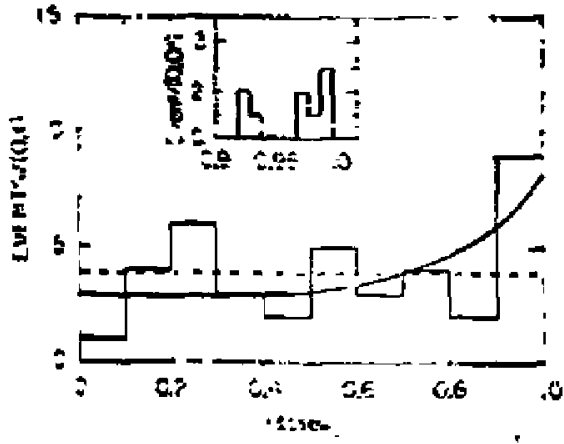

Fiq. 22. Projection of the 3-disungtomal engalor dtotribation onto the o ads. The dothed Iins is the distudbution expected tos eplnof, the solfe Iinie tor cpin-2. These expectetion. includs the effects of finte resolution and datestor afficiency. The inest wows the dietribution within the bin, -9 to 1.0 .

condidnte theorted in wich $\mathrm{O}^{-+}$and $\mathrm{z}^{++}$(or $\mathrm{o}^{++}$) objects apear, but cren these few show the intrinote mbiputty of their asatgment. In the Jaffe and Johnaon bag node2,26 the, would be thetr $0^{-}$ gluebell proticted at $1290 \mathrm{HeV}$, while the could werve as atther of thot: $2^{+t}$ glubalis predicted at 980 and 1590 NeV, or as the atulire mass ot objetes (1f we 1gnore our predialnery bpin determination).

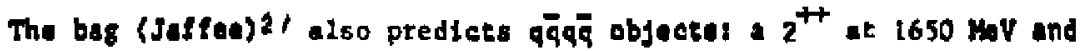
a $0^{++}$it 630 wat; we cannot exclude these.

The phyotedily appeoling nodel (velence gluons patred by color

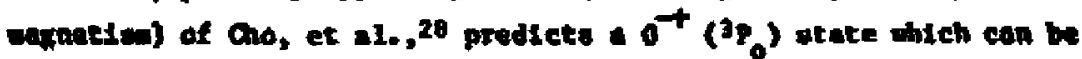
adjusted so fte $1(1440)$ exactly bet then hat only $60 x$ gioonfe con-

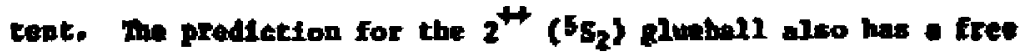

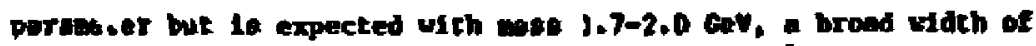
- 100 wat and $80 \%$ fluomic concent. In this scheme the $0^{+t}\left(I_{0}\right)$

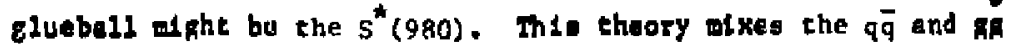
rooonentes warkedly and has opectfle predictlone for the relloo of $\checkmark+(8 \bar{q})$ Y and $\psi+(\pi g) Y$ for particles of stallar epin-parity, Flnally, an alcernectve explanation tor, is as a radial axalcatton of $q \bar{q}$, from which Cohen and Lpkta 29 predict $0^{+}$objecte at 1240 and $1500 \mathrm{kv}$.

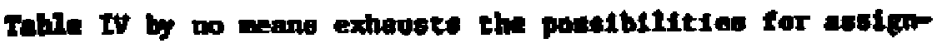

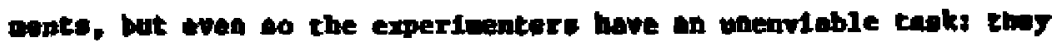

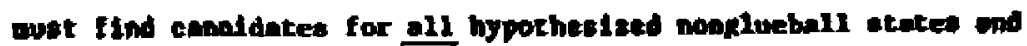


Plauslble Theoret1cal Interprelacions

of the New States in $\downarrow$-decily.

\begin{tabular}{|c|c|c|c|}
\hline Model & $\begin{array}{c}\text { Bag, } \\
\text { Jaffe } 8 \text { Johnson }\end{array}$ & $\begin{array}{l}\text { Color wi. } \\
\text { Cho et ll. }\end{array}$ & $\begin{array}{l}\text { Juag. } \\
\text { Jaffee }\end{array}$ \\
\hline Nature of state & $\begin{array}{c}(\mathrm{TE})^{2} \text { or }(\mathrm{TM})^{2} \\
\text { g1ueball }\end{array}$ & ${ }_{1}^{1} \mathrm{~S}_{\mathrm{o}}$ & $\bar{q} \bar{q} \bar{q}$ \\
\hline $\begin{array}{l}\text { Predicted Hass } \\
\text { and } x \text { glue }\end{array}$ & $\begin{array}{c}960 \text { or } 1590 ; \\
100 \%\end{array}$ & $\begin{array}{l}980 ; \\
70 \%\end{array}$ & $\begin{array}{l}650 ; \\
6 \pi\end{array}$ \\
\hline Correspondence & $?$ & $s^{*}(9801)$ & $?$ \\
\hline \multicolumn{4}{|l|}{ state $0^{-+}$} \\
\hline Model & Jaffe $\&$ Johnson & $\begin{array}{l}\text { Color Ar, } \\
\text { Cho et } 111 \text {. }\end{array}$ & $\begin{array}{l}\text { Cohen } 6 \\
\text { Lipkin }\end{array}$ \\
\hline Nature of stace & $\begin{array}{l}\text { (TE) (TM) } \\
\text { gI LEball }\end{array}$ & $\begin{array}{l}{ }^{3} \mathrm{Po} \\
\text { Rlueba:..I }\end{array}$ & $\begin{array}{l}q \overline{9} \text { radial } \\
\text { excilaston }\end{array}$ \\
\hline $\begin{array}{l}\text { Predicted Hass } \\
\text { and } z \text { glue }\end{array}$ & $\begin{array}{l}1290 \\
100 \%\end{array}$ & tuned to $1440 ;$ & (a) ${ }_{0 \mathrm{x}}^{1280 ;}$ (b) $\operatorname{lof}_{0 \mathrm{f}}$ \\
\hline Corraspondence & $:(1440) ?$ & $1(1440) ?$ & $\begin{array}{l}\text { (a) } \eta \pi \pi(1275) ? \\
\text { Stunt on } \\
\text { (b) } 1(1440) \text { ? }\end{array}$ \\
\hline \multicolumn{4}{|l|}{ State $2^{+++}$} \\
\hline Model & Jaffe st Johnson & $\begin{array}{l}\text { Color Wh, } \\
\text { Cho et El. }\end{array}$ & $\begin{array}{l}\text { Bag, } \\
\text { Jaffe }\end{array}$ \\
\hline Nature of State & $\begin{array}{c}(T E)^{2} \text { ar }(T M)^{2} \\
\text { Rluebal1 }\end{array}$ & $\stackrel{5}{S_{2}}$ & $q \bar{q} a \bar{a}$ \\
\hline $\begin{array}{l}\text { Predicted Mass } \\
\text { and } z \text { glue }\end{array}$ & $\begin{array}{l}960 \text { or } 1590 ; \\
1007\end{array}$ & $-1700 \underset{807}{(\Gamma-100)}$ & $\begin{array}{c}1550 ; \\
07\end{array}$ \\
\hline Cosrespondence & $0(1640) ?$ & $\theta(1640) ?$ & $\theta(1640) ?$ \\
\hline
\end{tabular}


have a few candidates left over, or must resort to poorly predicted values of asses, widths and relative branching ratios to try to climinate incorrect theories. The appearance of these strong radlative transitions, as predicted only for giveballs, wot cemain the most compling feature of these data.

VI. FUTURE DIRECTIONS

Resolution of the above dilemens lies in tultiple directions of research,

(A) Wore data on $4+Y X$ must be gathered to affira the $2^{++}$assignment for the $\theta(1640)$ and to look for more canddates.

(B) A search for different exclusive decay ;odes of the staces already found should be made, in resent and fucure data,

(c) A better understanding of the background and syscematics of the inclusive $Y$ disirlbution frow $t$, especially for high-x $\gamma^{\prime} s$, would ald in extracting the prodicted branchIng ratfos $1 / n, n / / n, \theta / E$, f'if that would constraln many moie1s.

(D) A precise measurement of $\eta+\gamma x$ should be nade to see If there is the predlcted recurrence of the bet of states geen in $\psi+\gamma X$, A second appearance of th1s strange asgcrtaent (by $q \bar{q}$ standards) would be a powecful arkument that the get is a direct result of sampling the color singlet Etate of two gluons.

\section{ACKNOWLEDAHENT:}

I would like to thank colleaques close to these works for their patienc discourses on their analyoes: D. G. Aschron, G. Galger, K. Kontgian, F. C. Porter and D. L. Scherre. I also chank T. Deorand for his repeated urgings that Crystal Ball data be exarIned for slueball effects and wany detalied discusstons of whe these wight be. 


\section{RTHEEHGSS}

1. Nebers of the Cryetel Ball Colluboratjon. Calltorala Intitute of Technology. Fyytes Departwent: C. Bawarde. R. Partridge, $C$. Puck and P. Porter. Harvard thiversity, Phyales Departenest A. Anereasyan, Y. F. Ou, W. Tollanan,

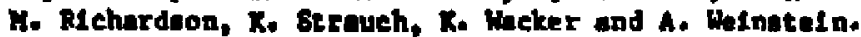
Frinceton Dnfrertity. Phyules Departenent: D. Anehwan, T. Burnete (visf(eor), H, Cats111-sforzt, D. Coyne, H, Joy, C. Ketmer and H. Sadrosindkf. Stentord If neor Aceelerator Cester: R. D. Bloon, F, Bulos, R. Chastnut, J. Esiger.

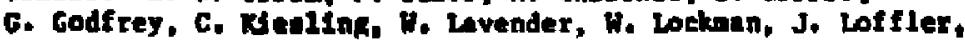
S. IInderen, S. Howe, H. Oteglia and D. Scharte. Stanford Univereity, Phyeles Doparteent and Hgh Znergy Phyoles Iabaratory: b. Calphan, k. Hofatedter, k. Hortaberger,

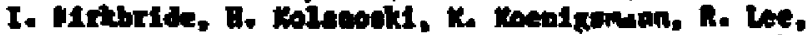
A. 1sternen, J. O'bat11y, A. Q-terteid, B. Pollock ond J. Topikine.

2. t. Fartridie et at. Pbys. ter. Lete. 44, $712(1990)$;

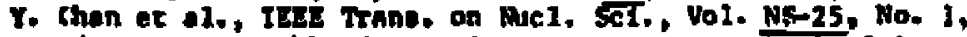
333 (1978); Y, Rirkbrtde et al., IEEE Trant. on WueI. Se1., Vo1. Ms-26, Ho, 1,1335 (1979).

3. Z. t1. L100m, Proceding of the 1979 International syopostiva on Lepton and Foton Intaractione at $H i$ in Energies, Augut $2 \pm 29$,

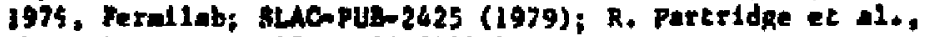
Phye + Nev. 1ete. 45, 1150 (19A0).

4. T. C. Porter, Procteding of siac summer Intettute on Particle

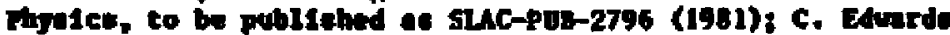
et a. suchib-2014 (1961).

5. 1. Iortel et a1. . Fhye. Let. 798, 492 (1978).

6. H. Grek1te, Ph.D. thante, steniford unIversity, suc neport 236 (1940).

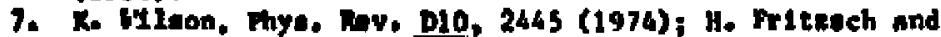
F. Mnkowek1, Muove cirtnto 30k, 393 (1975); P. Treund and Y. Nanbe, Phyo, Rav. Let. 34,1645 (1975); J. Kogut and c. tuacktad, Thro. Nov. 16, 395 (1975), K. Johanon, Phys. Let. 601, $201(1976)$.

8. F. Chanowite, Thye, Nov, DL2, 918 (1975).

9. 2. Cun and H. Voloshln, Ittip-9s (1976).

10. S. Irodaky, T. Docrond, R. Rorgan and D. Coyne, Phye, Lete. 738, 203 (197A).

11. The ebove erguant in thin partleular form wat polnted out by D. Scharre (Ref, 23).

12. R. poller and T. Malsh, Muel. Phys, B140, 449 (1978), and DesY prefrint 77/68.

13. J. I. Bforken, Proecedtige of Stac sumer Institute on Partiele Pugatee, sue hoort 224 (19A0).

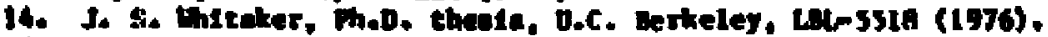

15. G. medel et al., Phye, Rew. tett. 33, 1324 (1977).

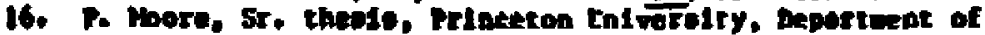

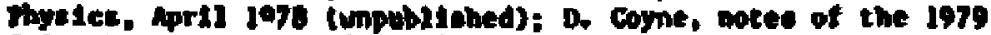
clitech acb workinop (unpubitined). 
17. U. tonan, notes of the 1979 Caltech OCD torkchop (unpublinbed); L. Calteri, Proceedinge of the 14 th Deneontre de Horlond, IA Ares, France (Karch 1979); M. Ronan et al, , Fhyo, Rev. Lett. 44, $367(1960)$.

18. D. seherre, Preceedinge of the $x$ International sy-poeive on Multiparticle Dmates, Coa, Indie, Eeptember 1979 (published In 1980); 6. Feldwan, Froceedinge of the I5th Rencontre de Mortend, Iat Area, France (Karch 1980); O. Mrage et al, Phya. Bav. Iate. 46. 114 (1980); D. Scharre, Phyo. Rev. D23, 43 (1981).

19. Unpubilehed preonentations by J. Toupkdae, sLac (Juty 1979), D. Coyne, SFsu (Wverbar 1979), H. Koleneutit, SLAC (Eoverber 1979), T. Bumete, U.C. Irvine (Deceobat 1979); D. Mechand, 8LAC-PUD-2550 (1980).

20. D. Selurre et al. Fhys. Lett. 975, 329 (19to).

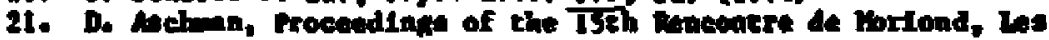
Ares. Presee (Wrech 1980).

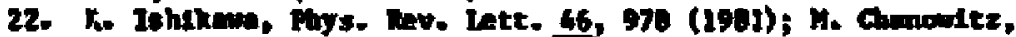

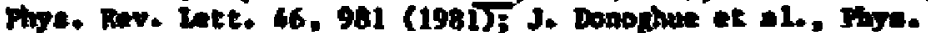
Let. 998, 416 (1985).

23. The cindidate (GF) 440 1s tered $G$ by $W$, Chanowtiz, GBs by K. Iohikaw and, by $\mathrm{B}$. Scharre.

24. C. Diontel at a1, Muc1. Phys, B169, 1 (1980).

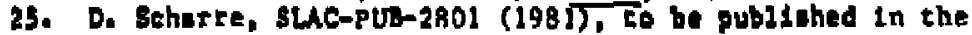
Procesdingt of the 1981 International gypoolu on Lepton and Photon Interactione at Kigh Energtes, Bann, Garniny, Alagast 24-29, 1901.

26. R. Jelfe and to Johnuon, Pyra. Iete, 60., 201 (1976).

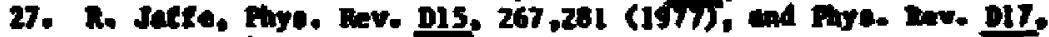
$1444(1976)$.

28. T. Gho at al., pax/LPThe 81/0a, peper eubdeted co 1981 International Syaposiog on Lepton and Fhoton Interactions at Figh Bnergles, Bonn, Gerniny, August 24-29, 1981.

29. I. Cohen and H. Lpkin, Mel. Phy. dist. 16 (1979). 